\title{
Kebijakan Kepariwisataan di Provinsi Aceh: Peluang dan Tantangan
}

\author{
Herizal, Saddam Rassanjani, Mukhrijal \\ Universitas Syiah Kuala, Banda Aceh, 23111, Indonesia
}

\begin{tabular}{|c|c|}
\hline ARTICLE INFORMATION & A B S T R A C T \\
\hline $\begin{array}{l}\text { Received: March 08, } 2021 \\
\text { Revised: March 23, } 2021 \\
\text { Accepted: April 21, } 2021 \\
\text { Available online: April 27, } 2021\end{array}$ & \multirow{4}{*}{$\begin{array}{l}\text { Tourism is a public sector that should be managed seriously to improve the livelihoods of many people. The } \\
\text { potential of Aceh's tourism must be encouraged by quality public policies so that all of its potential will be } \\
\text { maximized. In fact, there are still many weaknesses in public policies in the tourism sector that have rendered } \\
\text { Aceh's tourism potential in vain. This study aims to describe Aceh's public policy in the tourism sector in terms } \\
\text { of opportunities and challenges. The research approach used is a qualitative analysis through a literature } \\
\text { review that relies on secondary data, namely by collecting and mapping data from government documents in the } \\
\text { form of tourism plans, tourism regulations, work reports on tourism and similar studies on tourism policies. } \\
\text { The results of the study show that the Aceh Government has seen great opportunities in the tourism sector, } \\
\text { especially from halal tourism, but what remains a challenge until now is that the Government of Aceh has not } \\
\text { resolved problems related to tourism governance, tourism destination development and tourism branding. }\end{array}$} \\
\hline KEYWORDS & \\
\hline Public Policy; Tourism Sector; Aceh's Tourism; Halal Tourism & \\
\hline CORRESPONDENCE & \\
\hline
\end{tabular}

Phone: +6285260205353

E-mail: herizal.ismail@unsyiah.ac.id

\section{PENDAHULUAN}

Sektor kepariwisataan sudah lama menjadi primadona untuk menggerakkan perekonomian di berbagai tempat. Singh dan Unjum (2016) menyatakan pariwisata merupakan alat yang menarik dalam mendukung pertumbuhan ekonomi, terutama di negara berkembang. Lebih lanjut, pariwisata dipercaya dapat meningkatkan pembangunan, mengurangi kemiskinan, dan membuka banyak lapangan kerja (Li, Jin dan Shi, 2018). Oleh karena itu, sektor pariwisata bisa dikatakan sebagai sumber devisa negara yang memiliki begitu banyak multiplier effect bagi sosial dan ekonomi masyarakat dan negara. Sementara itu, potensi pariwisata secara global mencapai 1,5 miliar wisatawan pada tahun 2019 dengan pertumbuhan 3.8 persen pertahun (OECD, 2020). Besarnya potensi tersebut, maka tidak mengherankan jika berbagai negara termasuk Indonesia menjadikan sektor kepariwisataan sebagai prioritas utama pembangunan nasional.

Pemerintah Indonesia langsung bergerak membuat kebijakan Undang-Undang Nomor 10 Tahun 2009 Tentang Kepariwisataan. Dengan melihat peluang dari potensi yang sangat besar tersebut pemerintah berupaya membenahi sektor kepariwisataannya. Selanjutnya, master plan pengembangan kepariwisataan juga diformulasikan dalam PP No. 50 Tahun 2011, Tentang Rencana Induk Pembangunan Kepariwisataan Nasional (RIPKN) Tahun 2010-2025. Pengembangan pariwisata dihasilkan melalui implementasi rencana pembangunan kepariwisataan dengan melihat berbagai keunikan, keragaman, dan alam serta budaya yang khusus, menjadi keinginan tersendiri bagi masyarakat untuk berwisata. Pengembangan aspek wisata meliputi: destinasi kepariwisataan; kelembagaan kepariwisataan; industri dan pemasaran pariwisata. Dalam pengembangan pariwisata, ada beberapa daerah yang menjadi tujuan pariwisata nasional, yang terdiri dari 50 Destinasi Pariwisata Nasional (DPN). 88 Kawasan Strategis Pariwisata Nasional (KSPN) dan 222 Kawasan Pengembangan Pariwisata Nasional (KPPN).

Seluruh provinsi di Indonesia sudah terwakili 50 DPN yang ditetapkan termasuk diantaranya Provinsi Aceh. Terdapat 1 DPN, 3 KPPN dan 1 KSPN di Aceh, meliputi Destinasi Pariwisata Nasional Banda Aceh-Weh dan sekitarnya, Kawasan Pengembangan Pariwisata Nasional Banda Aceh dan sekitarnya, Kawasan Pengembangan Pariwisata Nasional Takengon dan sekitarnya, Kawasan Pengembangan Pariwisata Nasional Simeulue dan sekitarnya, dan Kawasan Strategis Pariwisata Nasional Weh dan sekitarnya. Di kawasan-kawasan tersebut tersimpan kekayaan pariwisata yang sangat luar biasa seperti di KSPN Weh dan KPPN Simeulue. Pada kedua kawasan ini, memiliki potensi keunggulan panorama laut yang bagus dan sangat indah, serta dengan budaya masyarakat setempat yang unik.

Aceh menawarkan banyak daya tarik atau aktraksi wisata yang eksotis di setiap sudut wilayahnya. Aktraksi ini jika menurut Yoeti (2002) dikutip dalam Rustiana, dkk (2019) terbagi menjadi empat jenis, yaitu aktraksi alam, aktraksi budaya, aktraksi sosial dan aktraksi terbangun. Potensi aktraksi alam Aceh sangat beragam, mulai dengan keindahan pantai dan dunia bawah laut yang terdapat di KSPN weh dan KPPN simeulue dan sekitarnya sampai dengan keindahan dataran tinggi pegunungan, danau dan sungai di KPPN Takengon dan sekitarnya termasuk Taman Nasional Gunung Lauser (TNGL). Di kawasan tersebut juga memiliki keanegaraman hayati yang sangat melimpah baik di daratan, udara maupun di perairan.

Potensi aktraksi budaya Aceh tercermin dari sejarah di masa masa lalu (cultural heritage) yang begitu beragam diantaranya sejarah kerajaan Aceh (the Kingdom of Aceh), sejarah 
kolonial, budaya islam, bencana gempa dan tsunami (smong). Kesenian seperti tari saman yang sudah banyak orang kenal, baik lokal maupun international yang diakui sebagai warisan dunia oleh UNESCO. Dan masih banyak lagi budaya dan nilai tradisional yang masih hidup dan berkembang di sejumlah daerah, misalnya didong, rapai, dan lainnya. Selain tari-tarian, Aceh memiliki berbagai potensi seperti adat-istiadat atau tradisi yang berbeda antara satu daerah dengan daerah lain dikawasan Provinsi Aceh, yang pada umumnya memilki penampilan yang berbeda. Tradisi yang unik atau khasnya dalam adat-istiadat Aceh yang menunjukan penampilan seperti Acara Kenduri Tolak Bala, Kenduri Blang, Kenduri Laot, Kenduri Glee, Kenduri Maulid Nabi, Turun Tanah Bayi, Rabu Abeh, Seumeuleung dan Peumeunap pada Makam Raja Meureuhom Daya di Lamno, Sunatan, dan berbagai adat istiadat dan seni tradisional aceh lainnya (Disbudpar Aceh, 2018).

Aktraksi sosial dapat dilihat dari cara hidup masyarakat Aceh dalam aktivitas kesehariannya. Kehidupan sosial masyarakat Aceh, yang menghayati ajaran Agama Islam di kehidupan sehari-hari, sehingga pada perilaku masyarakat sangat terikat dengan syariat Islam dan terkemas dalam adatistiadat, dan bentuk hukum. Gaya hidup yang islami tercermin dari interaksi sosial keseharian dalam kehidupan bermasyarakat yang memiliki daya tarik tersendiri bagi orang diluar Aceh.Daya tarik sosial lainnya berupa keberagaman bahasa daerah yang ada di Aceh dan peluang pertemuan sosial sambil menikmati kopi khas Aceh yang tersedia di ratusan kedai kopi yang ada di Banda Aceh.

Terakhir berupa aktraksi terbangun (man made) yang terdiri dari berbagai arsitektur bersejarah, bangunan dan monument, kebun, taman, pelabuhan, bandara, dan lain sebagainya. Di Aceh terdapat banyak warisan peninggalan masa lalu, yaitu Naskah/benda kuno, Masjid Raya Baiturrahman, Makam kuno, Kerkhof Peutjoet dan cagar budaya dan lainnya. Ditambah dengan bangunan monumental seperti museum tsunami, situs tsunami kapal PLTD apung, situs tsunami kapal diatas rumah, situs tsunami masjid lampuuk, situs tsunami masjid ulee lheu, kuburan massal korban tsunami dan masih banyak lainnya membuktikan bahwa Aceh memiliki potensi kepariwisataan yang beragam dan lebih besar (Disbudpar Aceh, 2014).

Aceh yang memiliki potensi wisata yang begitu besar, tidak sebanding dengan realitas yang ada, para wisatawan yang datang jauh dari ekspektasi. Walaupun ada laporan dari Dinas Kebudayaan Dan Pariwisata Aceh pada tahun 2018 terdapat peningkatan kunjungan wisatawan setiap tahunnya (20132017) rata-rata peningkatan sebesar 20,79\%. Pada tahun 2013 jumlah kunjungan wisatawan mencapai 1.118.178 orang, Pada tahun 2014 jumlah wisatawan yang berkunjung sekitar 1.428.262 orang. Pada tahun 2015 jumlah kunjungan wisatawan mencapai 1.717 .116 orang. Pada tahun 2016 jumlah wisatawan mencapai 2.154.249 orang. Dan pada tahun 2017 terus terjadi peningkatan yang berkunjung ke Aceh dengan jumlah 2.364.383 orang. Kunjungan para wisatawan yang datang ke Aceh terdiri dari wisatawan nusantara dan mancanegara. Kujungan wisatawan mancanegara mencapai sekitar 16,49\% pertahunnya. Sedangkan pengunjung nusantara pertahunnya mencapai rata-rata 20,97\% yang berkunjung ke Aceh (Disbudpar Aceh, 2018). Namun jika kita persentasekan dengan jumlah para pengunjung wisatawan mancanega secara nasional, maka wisatawan yang berkunjung ke Aceh sangatlah sedikit.
Contohnya seperti turis asal negara Malaysia yang paling banyak berkunjung ke Aceh, tetapi tidak sampai satu persen jika kita bandingkan secara nasional. Berikut disajikan Tabel 1. Kunjungan Turis Mancanegara Provinsi Aceh Tahun 2018.

Table 1. Kunjungan Turis Mancanegara Prov. Aceh tahun 2018

\begin{tabular}{llll}
\hline Asal Negara & Nasional & Aceh & Persentase \\
\hline Malaysia & $2,503,344$ & 24,213 & 0.97 \\
Inggris & 392,112 & 2,340 & 0.6 \\
Tiongkok & $2,139,161$ & 860 & 0.04 \\
Amerika Serikat & 387,856 & 762 & 0.2 \\
Australia & $1,301,478$ & 538 & 0.04 \\
Perancis & 287,917 & 419 & 0.15 \\
Jerman & 274,166 & 373 & 0.14 \\
Mesir & 18,075 & 348 & 1.93 \\
Thailand & 124,153 & 296 & 0.24 \\
Kanada & 97,908 & 246 & 0.25 \\
Lainnya & $8,284,135$ & 2,881 & 0.03 \\
Total & $15,810,305$ & 33,276 & 0.21 \\
\hline
\end{tabular}

Sumber: BPS Aceh, 2019

Pada penjelasan tabel 1, Malaysia adalah negara mayoritas penyumbang wisatawan terbesar ditingkat mancanegara yang berkunjung ke Aceh. Hal ini disebabkan oleh budaya melayu dan agama yang memiliki hubungan kedekatan dengan Aceh sehingga merasa nyaman untuk berkunjung. Factor sejarah dan agama Islam mungkin menjadi salah satu alasan, dimana mayoritas warga Negara Malaysia sama dengan masyarakat Aceh (Swesti, 2019). Selain itu kedekatan geografis juga dapat menguatkan alasan warga negara Malaysia suka berkunjung ke Aceh. Pada tahun 2015, tercatat 77,32 persen turis mancanegara yang datang ke Aceh berasal dari Malaysia (Rindrasih, 2019). Walaupun sudah didukung banyak faktor kesamaan di atas, jumlah warga negara Malaysia yang berkunjung ke Aceh masih kalah besar dibandingkan dengan daerah lain di Indonesia seperti ke Jakarta (sebanyak 321.489 wisatawan), Batam (229.140 wisatawan), Bali (192.516 wisatawan), Sumatera Utara (134.381), dan Jawa Barat (104.857 Wisatawan) (BPS Aceh, 2019).

Dari data tersebut menunjukkan bahwa dibandingkan daerah lain di Indonesia, Aceh terlambat menyadari dan memulai mengembangkan sektor kepariwisataan untuk meningkatkan kesejahteraan di daerahnya. Ditambah berdasarkan pengukuran indeks kepariwisataan tahun 2016, Aceh masih kalah jauh dari daerah lain di Indonesia terutama yang menempati indeks pariwisata tertinggi seperti Provinsi Bali, Jawa Timur, Yogyakarta, Riau, Jawa Barat dan Jawa Tengah (Saleh dan Anisah, 2018). Padahal potensi kepariwisataan yang dimiliki Aceh tidak kalah hebat dengan daerah-daerah tersebut.

Kondisi seperti ini tentu memunculkan pertanyaan bagaimanakah kebijakan publik dalam mengembangkan sektor kepariwisataan yang selama ini telah dijalankan Pemerintah Aceh. Apakah pemerintah Aceh sudah menyadari peluang dari potensi yang sangat besar tersebut sehingga diperlukan kejelian dan keseriusan Pemerintah Aceh dalam menformulasikan kebijakan publik yang berkualitas di sektor kepariwisataan. Karenanya kebijakan publik merupakan instrument pemerintah dalam menyelesaikan masalah-masalah publik dan meningkatkan pembangunan untuk kesejahteraan. 


\section{METODE}

Pada penelitian ini, penulisan menggunakan metode pendekatan literature review. Literature review digunakan untuk memperoleh atau mengumpulkan atau memetakan data dari hasil penelitian sebelumnya tentang kepariwisataan. Jenis data yang diperoleh yaitu data sekunder yang dideskripsikan dalam bentuk naratif atau bentuk lainnya sesuai dengan kebutuhan tampilan data.

Penelitian sebelumnya yang dianggap relevan dengan penelitian ini yang ditelusuri menggunakan google scholar, dipilih sejumlah 15 artikel jurnal. Sumber pendukung lainnya berupa dokumen pemerintah seperti Rencana Induk Pembangunan Kepariwisataan Nasional 2010-2025, Rencana strategis Disbudpar Aceh tahun 2012-2017 dan tahun 20172022, Rencana Kerja Disbudpar Aceh 2014-2018, LAKIP Disbudpar Aceh 2014-2018. Dan data yang diperoleh dari media online seperti aceh.tribunnews.com, viva.co.id, dan crescentrating.com. Selanjutnya, data yang ditemukan dianalisis menggunakan tematik analisis dengan tiga tahapan yaitu menemukan persamaan, menemukan perbedaan dan memberikan pemaknaan melalui proses intepretasi data.

\section{HASIL DAN PEMBAHASAN}

Menurut Goeldner dan Ritchie (2012), kebijakan kepariwisataan adalah seperangkat regulasi, pedoman atau aturan, arahan, dan tujuan dan strategi pengembangan dan promosi yang menyediakan kerangka kerja di dalamnya, dimana keputusan kolektif dan individu mempengaruhi secara langsung pengembangan pariwisata untuk kegiatan sehari-hari maupun jangka panjang dalam suatu destinasi kepariwisataan. Sehingga Edgell, Sr., (2008) menambahkan kebijakan kepariwisataan berhubungan dengan perencanaan kepariwisataan, dimana perencanaan tersebut akan memperkuat kedudukan atau posisi kebijakan kepariwisataan dalam pembangunan. Dalam hal ini, model perencanaan kepariwisataan melingkupi perumusan Visi dan Misi, ditindaklanjuti dengan serangkaian strategi, taktik, sasaran dan tujuan untuk pembangunan kepariwisataan. Kebijakan dalam perencanaan kepariwisataan harus berfungsi, berjalan secara efektif sebagai arah pengembangan suatu destinasi kepariwisataan (Murdiastuti, Rohman, dan Suji, 2014).

Menurut UN-WTO (United Nations World Tourism Organiation), pemerintah memiliki posisi penting dalam memfokuskan kebijakan kepariwisataan, dan bertanggungjawab terdapat beberapa point, seperti: (a) mempersiapkan legislasi, rule, kontroling dalam kepariwisataan, warisan budaya, pelestarian budaya dan perlindungan lingkungan, (b) Membangun Framework atau kerangka operasional, dimana sector public dan sector privat terlibat dalam menggerakan sector kepariwisataan. (c) Pemerintah menyediakan dan menfasilitasi berbagai kebutuhan yang mendorong peningkatan kualitas sumber daya manusia, seperti menjamin pendidikan, pelatihan yang professional, agar dapat menyuplai tenaga kerja di bidang sector pariwisata. (d) Membangun infrastruktur seperti transportasi darat, laut, udara, dan menyediakan kelengkapan prasarana komunikasi. (e) Kebijakan pariwisata disusun dan direncanakan secara kongkrit, yang didalamnya; Pertama, mengevaluasi kekayaan asset pariwisata, budaya, alam serta mekanisme atau cara melindungi dan melestarikannya; Kedua, katagori produk wisata yang memiliki keunggulan komperatif dan kompetitif; Ketiga, membuat ketentuan dan persyaratan yang menyediakan infrastruktur serta suprastruktur yang berdampak terhadap performance pariwisata; Keempat, pengkalaborasian program yang dibiayai untuk aktivitas pariwisata, baik sector public maupun sector privat (Ridwan, M dan Aini, 2019).

\section{Master Plan Kepariwisataan}

Kebijakan kepariwisataan terkait erat dengan perencanaan kepariwisataan. Penyediaan komponen-komponen penting untuk membangun kepariwisataan bisa dilakukan jika arah kebijakan dan strategi pemerintah sudah tepat mencapai tujuan tersebut. Di Indonesia terdapat tiga rencana induk pengembangan kepariwisataan yang disepakati secara terpisah yaitu ditingkat Nasional, Provinsi dan Kabupaten/Kota. Ditingkat Nasional, Rencana Induk Pembangunan Kepariwisataan Nasional atau disingkat dengan RIPPARNAS, yang disetujui pada 2010 hingga tahun 2025 dan ada rencana aksi strategis yang diterbitkan setiap tahun untuk menetapkan kegiatan terkait dalam mencapai tujuan master plan nasional.

Pada tingkat provinsi, RIPPARDA atau Rencana Induk Pembangunan Kepariwisataan Daerah, khusus di Provinsi Aceh disebut Rencana Induk Pengembangan Kepariwisataan Aceh (RIPPA). Qanun Aceh tentang kepariwisataan yang disahkan pada tahun 2013 sudah menyebutkan RIPPA sebagai pedoman, arah dan strategi pengembangan kepariwisataan tingkat provinsi tetapi hingga kajian ini dibuat rencana induk tersebut belum disahkan. Sehingga untuk perencanaan tingkat Provinsi, Pemerintah Aceh masih banyak mengacu pada perencanaan pusat (RIPPARNAS) walaupun belum secara komprehensif mengakomodir pembangunan kepariwisataan Aceh. Terakhir RIPPARDA kabupaten/kota yang beberapa sudah terbentuk, seperti RIPPARKA Aceh Timur, RIPPARKOT Langsa, RIPPARKOT Sabang, dan RIPPARKA Aceh Singkil.

RIPPARNAS, RIPPARDA Provinsi dan RIPPARDA Kabupaten/Kota diperlukan sebagai pedoman dan strategi operasional dalam pembangunan pariwisata, bagi pelaku pariwisata, sosial dan budaya, dan pelaku ekonomi baik di tingkat pusat dan di daerah. Rencana induk pengembangan kepariwisataan menjadi sangat penting karena beberapa hal, pertama, menggariskan tujuan pengembangan yang sesuai terhadap potensi pariwisata baik dari sisi manajemen, SDM, produk, pasar, dan lain-lain, sehingga dapat tumbuh, maju secara positif dan berkelanjutan dalam pembangunan wilayah untuk kesejahteraan masyarakat. Kedua, memfasilitasi peranan dari stakeholders, baik antar pelaku pariwisata, lintas sector, wilayah supaya dapat mendorong kemajuan pariwisata, secara sinergis dan terpadu. Beikut disajikan pada Gambar 1. Peta Pengembangan DPN Banda Aceh -Weh dan sekitarnya dalam RIPPARNAS 2010-2025. 


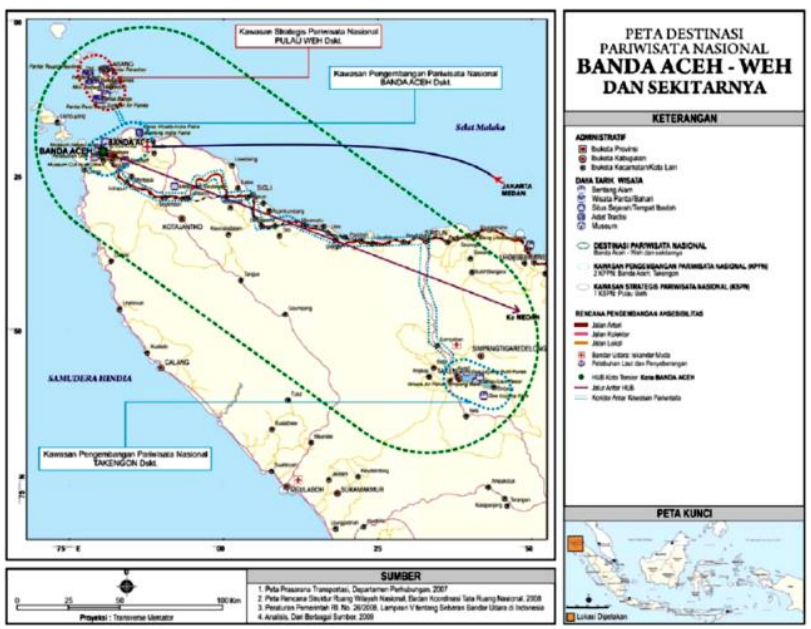

Gambar 1. Peta Pengembangan DPN Banda Aceh -Weh dan sekitarnya dalam RIPPARNAS 2010-2025

Pemerintah Aceh belum mempunyai master plan tersendiri untuk membangun sektor kepariwisataan di Aceh. Walaupun sudah dalam proses perancangan tetapi rancangan kebijakan pemerintah tersebut belum ditetapkan secara resmi (terlegitimasi) sehingga belum bisa diimplementasikan. Dalam hal ini, Aceh masih sangat tergantung kepada pemerintah pusat sebagaimana tertuang dalam dokumen RIPPARNAS 2010-2025.

Master plan nasional pengembangan pariwisata, memiliki empat tujuan utama: pertama, mengembangkan destinasi yang aman, nyaman, menarik, mudah diakses, ramah lingkungan dan menumbuhkan ekonomi di tingkat nasional, regional dan masyarakat. Kedua, Mengkoordinasikan pemasaran yang berkualitas tinggi dan dapat dipercaya untuk mendorong kunjungan dari dalam negeri dan pasar luar negeri.Ketiga, Menciptakan sektor bisnis pariwisata yang kompetitif dan profesional dan merangsang kemitraan yang bisa memainkan peran mereka dalam mengatasi dampak lingkungan dan sosial dari pariwisata.Keempat, Mendorong kemajuan menuju pengembangan pariwisata berkelanjutan melalui keterlibatan aktif pemerintah daerah, sektor swasta dan masyarakat.

Pembahasan master plan perlu dipacu oleh Pemerintah Aceh supaya sektor pariwisata bisa bergeliat untuk menggerakkan perekonomian Aceh yang lesu. Apalagi Menurut UN-WTO, peran pemerintah dalam menentukan arah pembangunan sektor kepariwisataan sangat urgen dengan tahapan yang sistematis. Pembangunan juga perlu mempertimbangkan kelestarian alam dan sumberdaya yang sudah ada (pembangunan berkelanjutan). Pemerintah Aceh tidak boleh puas dengan hanya mengeluarkan aturan-aturan yang mengikat pelaku sektor pariwisata. Misalnya Qanun Aceh Nomor 8 Tahun 2013 Tentang Kepariwisataan yang menggariskan beberapa hal yang pada intinya adalah penegasan terhadap penyelenggaraan kepariwisataan yang menjunjung nilai-nilai Islam dan kearifan lokal. Regulasi yang diterbitkan juga tidak boleh kontra-produktif dengan tujuan pembangunan pariwisata itu sendiri untuk mengangkat hajat hidup masyarakat terutama kalangan miskin. Pemerintah Aceh harus bisa merangkul masyarakat dan kalangan swasta agar peduli untuk sama-sama menggeliatkan aktivitas kepariwisataan. Tanpa political will yang kuat dan upaya nyata yang dilakukan Pemerintah Aceh beserta birokrasinya, pembangunan sektor kepariwisataan Aceh hanya akan jalan ditempat.

\section{Halal Based Policy}

Kebijakan publik sektor kepariwisataan di Provinsi Aceh akan diarahkan menuju pariwisata halal. Tentu keputusan tersebut dilatar belakangi oleh faktor mayoritas penduduk Aceh adalah Muslim. Agama Islam sangat kuat mempengaruhi budaya dan cara hidup orang Aceh (Rindrasih, 2019). Faktor lainnya karena trent peningkatan industri pariwisata halal di dunia yang mencapai 131 juta wisatawan muslim pada tahun 2017 (Mastercard-CrescentRating, 2018). Tingginya minat berwisata dari kalangan muslim tersebut merupakan peluang bagi sektor pariwisata di negara muslim untuk mengembangkan pariwisata halal.

Pada tahun 2013, Pemerintah Indonesia mempromosikan pariwisata halal di Halal Expo 2013 dan Forum Halal Global di Kemayoran, Jakarta. Menangkap peluang tersebut, Pemerintah Aceh pada tahun 2016 menyatakan pariwisata halal sebagai produk pariwisata utamanya dan mendukung pengembangannya dan promosi. Semua pihak termasuk Dewan Perwakilan Rakyat Aceh juga mengakui pariwisata halal sebagai merek utama pengembangan pariwisata Aceh. Akhirnya, Kementerian Pariwisata menambahkan Aceh ke daftar tujuan wisata halal nasional dan menyediakan anggaran, program dan promosi (Disbudpar Aceh, 2016).

Pada tahun 2016, Aceh berhasil dalam kopetensi pariwisata halal sebagai salah satu nominator nasional yang diselenggarakan Kementerian Pariwisata Republik Indonesia. Selanjutnya Aceh juga ikut dalam "World's Halal Awards 2016" dengan memenangkan penghargaan yaitu "World's Best Airport for Halal Travelers" dan "World's Best Halal Cultural Destination". Sebagai wilayah yang sedang bangkit dari keterpurukan akibat konflik dan bencana alam, dengan mulai berbenah mengembangkan industri kepariwisataannya.Pencapaian tersebut tentu menjadi kebanggaan tersendiri bagi masyarakat Aceh terutama bagi Pemerintah Aceh. Setelah menjadi salah satu destinasi wisata halal unggulan nasional dan mulai diperhitungkan dalam industri pariwisata dunia tentu menjadi suatu pertimbangan yang matang untuk mencapai keberhasilan, baik secara nasional maupun mancanegara. Ini menjadi tantangan bagi Pemerintah Aceh maupun masyarakat Aceh dalam mengelola sektor wisata halal. Aceh sebagai tuan rumah, tentu harus memberikan pelayanan terbaik dalam menyambut para wisatawan dengan pelayanan berbasis halal (Jaelani, 2017).

Pariwisata halal dapat dikategorikan sebagai ceruk pariwisata baru. Praktik kepariwisataan halal di Aceh dapat dilihat pada diwajibkannya restoran untuk hanya menyediakan makanan halal dan pelayanan hotel kepada semua tamu yang sesuai dengan ajaran Agama Islam, seperti arah kiblat, makanan halal, minuman tidak beralkohol, ruang shalat dan panggilan adzan. Ketersediaan penilaian dan sertifikat untuk hotel ramah muslim atau halal dianggap sebagai salah satu yang penting untuk menarik wisatawan muslim ke Aceh. Apalagi banyak tur paket menarik bagi wisatawan; paket-paket tersebut termasuk kunjungan ke masjid Baiturahman, pesantren atau panti asuhan, serta suasana ramadhan atau perayaan keagamaan idul fitri dan idul adha.Beberapa bahkan menawarkan wisata warisan Islam untuk menunjukkan kepada wisatawan sejarah dan budaya peradaban Islam di Aceh (Rindrasih, 2019).

\section{Branding Wisata Halal}

Promosi wisata halal yang mulai didengungkan Pemerintah Aceh ditindaklanjuti dengan kebijakan pembuatan branding 
baru yang bernuasa islami. Pendekatan seperti Tourism destination branding menjadi umum digunakan untuk mengelolaan dan mempromosi suatu destinasi wisata, bahkan telah menjadi tren di kalangan pemasaran destinasi wisata halal .Hal ini menjadi penting untuk menggunakan pendekatan tertentu karena berkaitan dengan nilai reputasi atau citra dan pengembangan sebuah daerah (Pereira, Correia, dan Schutz, 2012).

Sebelumnya pada tahun 2012, Pemerintah Aceh telah mencanangkan "Visit Aceh 2013" dengan tujuan mempromosikan pariwisata Aceh pada tingkat nasional dan internasional di Kementerian Pariwisata dan Ekonomi Kreatif Republik Indonesia. Branding image yang ditampilkan adalah "Aceh Serambi Mekah, Kaya Budayanya dan Indah Alamnya”. Dengan momentum ini, menjadi media strategis dalam menyampaikan pesan kepada seluruh kalangan bahwa Aceh telah siap sebagai daerah atau tujuan wisata dengan berbagai daya tarik dan keunikan wisatanya seperti wisata alam, wisata budaya, sejarah masa lalu, dan keramahan masyarakanya (Disbudpar Aceh, 2014).

Seiring berjalannya waktu, konsep dan pengembangan kepariwisataan di Aceh semakin matang menuju pariwisata halal. Branding sebelumnya dianggap masih terlalu umum dan kurang representatif dalam menunjukkan identitas Aceh sebagai daerah yang islami dan harus diganti dengan branding baru. Untuk itu Pemerintah Aceh pada tahun 2016 mengemas sebuah branding baru yakni "The Light of Aceh" (Cahaya Aceh). Branding baru tersebut dapat terwujud berkat dukungan seluruh stakeholder terutama pemerintah kabupaten/kota seluruh Aceh. Branding "The Light of Aceh" dinilai lebih dapat merefleksikan identitas masyarakat Aceh dalam Syariat Islam yang "Rahmatan Lil 'Alamiin". Mengajak pada nilai-nilai moral kebaikan, kemakmuran, dan memberikan pencerahan serta manfaat kepada semua makhluk (Disbudpar Aceh, 2016a).

Pada tahun 2019 rupanya pihak Pemerintah Aceh juga belum puas terhadap kinerja branding "The Light of Aceh". Terbaru, untuk lebih memperkuat branding halal, pada Desember 2019, Plt Gubernur Aceh yang didampingi oleh Ketua Tim Percepatan Wisata Halal Aceh dan Kepala Dinas Kebudayaan dan Pariwisata Aceh melaunching branding pariwisata yaitu "Aceh Halal Tourism" atau "Wisata Halal Aceh". Dengan Branding "Aceh Halal Tourism" tersebut mereka meyakini akan menjadi strategi baru dari Pemerintah Aceh untuk menarik wisatawan muslim, baik lokal, nasional maupun internasional agar mau berkunjung ke tanah rencong. Pada kesempatan tersebut, Kepala Dinas Kebudayaan dan Pariwisata Aceh juga menegaskan bahwa dengan hadirnya branding baru Pariwisata Aceh tidak terlepas dari branding "The Light Of Aceh" yang sudah ada sebelumnya, dan bukan untuk menggantikannya (Tim Viva, 2019).

\section{Event Pariwisata Halal}

Event pariwisata adalah stimulan penting di bidang kepariwisataan, dan menjadi hal yang prioritas untuk dilakukan dalam mengembangkan dan rencana pemasaran sebagian besar daerah tujuan wisata. Dari sisi penawaran, tujuan dikembangkan, difasilitasi dan dipromosikan semua jenis event pariwisata suatu daerah adalah untuk menarik wisatawan terutama diluar masa puncak liburan.Berfungsi sebagai katalis untuk pembaharuan suatu daerah, meningkatkan infrastruktur dan kapasitas suatu daerah tujuan wisata (Getz, 2008).

Kebijakan Pemerintah Aceh, melalui Dinas Kebudayaan dan Pariwisata, setiap tahunnya berbagai agenda dan event wisata yang disiapkan yang tercantum dalam Calender of Event (CoE). Acara-acara pariwisata tersebut diharapkan bisa menarik minat para wisatawan nusantara dan internasional untuk berwisata ke ujung paling barat Pulau Sumatera tersebut. Berikut disajikan Tabel 2. Acara-Acara Kepartiwisataan di Provinsi Aceh Tahun 2015-2019.

Table 2. Acara-Acara Kepartiwisataan di Provinsi Aceh Tahun 2015-2019

\begin{tabular}{|c|c|c|}
\hline Tahun & $\begin{array}{c}\text { Jumlah } \\
\text { Acara }\end{array}$ & Acara Unggulan \\
\hline 2015 & 24 & $\begin{array}{l}\text { Kota Sabang (International Diving } \\
\text { Festival), Simeulu (International Surfing } \\
\text { Championship), Aceh Tenggara } \\
\text { (International Rafting Championship), } \\
\text { Banda Aceh (Aceh International Islamic Art } \\
\text { and Culture Festival, Aceh Culinary } \\
\text { Festival, Aceh Coffee Festival, Aceh Tengah } \\
\text { (Pacuan Kuda Tradisional). }\end{array}$ \\
\hline 2016 & 9 & $\begin{array}{l}\text { Banda Aceh (Aceh Culinary Festival, Aceh } \\
\text { Coffee Festival, dan Aceh International } \\
\text { Rapa'i Festival), Aceh Tengah (Pacuan } \\
\text { Kuda Tradisional). }\end{array}$ \\
\hline 2017 & 35 & $\begin{array}{l}\text { Bener Meriah (Festival Pacuan Kuda } \\
\text { Tradisional), Banda Aceh (Pekan Nasional } \\
\text { Kontak Tani Nelayan Andalan, Coffee } \\
\text { Festival, Aceh Culinary Festival, dan } \\
\text { Peringatan 13th Tsunami Aceh), Gayo Lues } \\
\text { (Saman 10.001) di Gayo Lues, (Sail Sabang) } \\
\text { di Sabang, dan Aceh Tengah (Festival } \\
\text { Danau Laut Tawar). }\end{array}$ \\
\hline 2018 & 10 & $\begin{array}{l}\text { Banda Aceh (Pekan Kebudayaan Aceh VII, } \\
\text { Aceh Culinary Festival, Coffee) dan Pacuan } \\
\text { Kuda Tradisional Aceh Tengah. }\end{array}$ \\
\hline 2019 & 100 & $\begin{array}{l}\text { Bener Meriah (Pacuan Kuda Tradisional), } \\
\text { Banda Aceh (Maulid Raya Kota Banda } \\
\text { Aceh, Festival Mie Aceh, Festival Meugang, } \\
\text { Aceh Culinary Festival, Aceh Coffee } \\
\text { Festival, Bireun (Aceh International Rapa'i } \\
\text { Festival), Takengon (Festival Panen Kopi), } \\
\text { dan Sabang International Freediving } \\
\text { Championship, Peringatan 15th Tsunami } \\
\text { Aceh di Banda Aceh. }\end{array}$ \\
\hline
\end{tabular}

Sumber: Disbudpar.acehprov.go.id, 2019 dan Saleh dan Anisah, 2018

Meningkatnya popularitas pariwisata halal karena meningkatnya minat kalangan muslim untuk berwisata. Berbagai negara melakukan banyak persiapan untuk menyambut peluang ini termasuk Pemerintah Aceh. Pariwisata halal sendiri mengacu pada penyediaan produk dan layanan pariwisata yang memenuhi kebutuhan wisatawan Muslim untuk memfasilitasi ibadah dan makanan yang sesuai dengan ajaran Islam. Oleh karena itu, pariwisata halal adalah jenis pariwisata yang menganut nilai-nilai Islam, dan memungkinkan penganut agama untuk berhasil menjadi bagian dari dunia kontemporer dengan cara yang konsisten dengan nilai dan 
praktik mereka. Keberhasilan penerapan wisata halal jika tuan rumah bisa meyakinkan wisatawan dengan menawarkan fasilitas dasar dan pelayanan yang mereka butuhkan. Untuk itu pemerintah Aceh menyiapkan kebijakan yang mengarah pada wisata halal (halal based policy) diantaranya menggaungkan branding "Aceh Halal Tourism" dan mematangkan berbagai event pariwisata halal di seluruh Aceh untuk menarik wisatawan terutama kalangan muslim diseluruh dunia.

\section{Tantangan Kebijakan Sektor Kepariwisataan Aceh}

Terlepas dari tujuan dan kebijakan publik Pemerintah Aceh yang ada, sejumlah tantangan tetap muncul, terutama terkait dengan tata kelola kepariwisataan, pengembangan destinasi pariwisata dan pemasaran (branding) sektor kepariwisataan. Mengenai tata kelola kepariwisataan, yang masih lemah dibidang kualitas sumber daya manusia (SDM) pada kepariwisataan, terkhusus pada persolan pengelolaan dan pelayanan pariwisata menjadi salah satu kendala utama pengembangan kepariwisataan Aceh. Saat ini ada kekurangan lembaga pendidikan tinggi yang cocok untuk menyediakan tenaga kerja yang terlatih untuk sektor pariwisata.Beberapa organisasi kepariwisataan yang sudah tumbuh bahkan membutuhkan perbaikan-perbaikan. Profesionalitas adalah hal yang sangat patut untuk dipertimbangkan dalam mengelola sektor kepariwisataan, sebab tingkat kepuasan yang diterima mempengaruhi wisatawan untuk menceritakan kembali pengalamannya ketika berkunjung ke suatu destinasi wisata (OECD, 2020).

Pengembangan destinasi pariwisata merupakan hal yang sangat menantang di Aceh karena sifat fisik daerah, efek dari perubahan iklim, fenomena terkait cuaca alami, kesulitan dengan konektivitas dan infrastruktur dasar akan membutuhkan investasi yang sangat besar. Ada masalah ketika memilih lokasi yang tepat untuk pengembangan destinasi pariwisata di Aceh.Khususnya di wilayah pesisir Aceh yang masih sangat rentan oleh bencana gempa bumi dan tsunami. Beberapa gempa bumi telah melanda Aceh sejak 2004; misalnya, tiga puluh sembilan orang tewas dalam gempa berkekuatan 6,1 SR pada tahun 2013, dan sembilan puluh dua meninggal akibat gempa berkekuatan 6,5 SR pada tahun 2016. Tempat-tempat wisata yang ada saat ini sebagian besar terletak di daerah pantai dan di pusat kota yang sangat parah terkena dampak tsunami 2004. Pertumbuhan pariwisata sebagai sumber mata pencaharian bagi banyak orang dapat meningkatkan kerentanan mereka, karena pariwisata sensitif terhadap peristiwa bencana.Selain itu, dapat berisiko tinggi kepada wisatawan karena mereka mungkin tidak terbiasa dengan prosedur evakuasi selama peristiwa bencana (Rindrasih, 2019).

Citra Aceh yang buruk di beberapa pasar nasional dan internasional memerlukan kegiatan promosi yang lebih efektif.Untuk mendukung pengembangan kepariwisataan di Aceh, kekerasan dan konflik politik harus dikurangi.Sebagai hasil dari periode konflik yang panjang ada rasa saling curiga yang masih muncul di Aceh. Dan ada sejumlah konflik skala kecil yang tidak terkait dengan para mantan kombatan telah mengancam keamanan dan keselamatan kota; misalnya, ada beberapa insiden sebelum pemilu 2009 dan 2012, dan kekerasan jalanan sepanjang tahun.

Penerapan hukum syariah bisa menjadi permasalahan ketika mencoba menarik wisatawan baru, karena kata "syariah" mungkin terkait dengan terorisme, ISIS atau kegiatan radikal lainnya. Seperti juga disorot di media Barat, ada banyak Islamofobia, dan itu bisa menurunkan keinginan orang untuk berkunjung ke Aceh. Selain itu, dari perspektif promosi, itu melemahkan kepercayaan diri dalam membangun merek tujuan berdasarkan nilai-nilai Islam, karena kurangnya minat dari calon wisatawan Barat, yang memiliki kesalahpahaman tentang Islam. Seperti yang disebutkan oleh Timothy dan Iverson (2006), nilai-nilai Islam tidak mendukung pemaparan tubuh perempuan, dan ada pandangan stereotip untuk kalangan muslim bahwa mereka konservatif dan praktik anti-Barat sehingga tidak menarik bagi wisatawan Barat (Rindrasih, 2019).

Tantangan lainnya datang dari masyarakat Aceh sendiri.Beberapa komunitas masyarakat telah menolak kegiatan pariwisata karena mereka menganggapnya tidak Islami. Wisatawan dianggap sering melanggar norma dan aturan adat seperti yang diatur dalam Qanun. Yang berarti bahwa tindakan tertentu seperti konsumsi makanan dan minuman yang memabukkan, perilaku tidak bermoral, perjudian, dan lain-lain dilarang, dan larangan itu berlaku untuk semua orang, termasuk wisatawan. Bukti bahwa kuatnya penolakan terhadap kegiatan pariwisata adalah gagalnya pembangunan Best Western Hotel pada tahun 2012 (Hasyim (ed), 2012).

Penguatan promosi dengan kemasan "The Light of Aceh" dan "Aceh Halal Tourism" bisa membersihkan citra buruk Aceh di pasar nasional dan internasional, juga memahamkan masyarakat terkait keuntungan dari pariwisata. Tetapi berdasarkan hasil mini riset dari wiwin (2019) ke beberapa stakeholder di Banda Aceh dan sekitarnya menunjukkan bahwa promosi pariwisata Aceh belum maksimal. Mereka masih belum mengetahui branding "The Light of Aceh" dengan alasan belum adanya sosialisasi dari Dinas Budaya dan Pariwisata terhadap branding tersebut. Pihak travel mengatakan bahwa di bus angkutan, yang diwajikan hanyalah stiker Wonderfull Indonesia, sedangkan untuk stiker The Light of Aceh belum ada sosialisasi dan mereka belum mengetahuinya. Pengusaha souvenir ada yang menjual oleh-oleh yang berlogo "The Light of Aceh" namun itu inisiatif dari mereka sendiri bukan dari dinas terkait.

Selain melihat pengetahuan dari pengusaha souvenir dan travel, dilakukan juga pengukuran pengetahuan terhadap duta wisata yang ada di Aceh. Penilaian duta wisata ini mencakup tentang pentingnya branding bagi kebehasilan wisata halal dan peran mereka sebagai duta wisata dalam mempromosikan branding tersebut. Hasilnya dapat disimpulkan bahwa duta wisata sangat mendukung dan mengetahui sudah terjadi peningkatan wisatawan yang datang ke Aceh sejak adanya branding tersebut. Namun demikian, duta wisata ini juga belum sepenuhnya mempromosikan branding tersebut, mereka lebih terfokus untuk mempromosikan wisata alamnya. Mereka juga mengatakan bahwa branding wisata halal "The Light of Aceh" masih belum sesuai dengan keadaan di lapangan dalam mewujudkan wisata halal.

Penilaian dan pengetahuan masyarakat terhadap branding "The Light of Aceh" menunjukkan bahwa masyarakat masih sangat kurang pengetahuannya terhadap branding dan wisata halal ini. Masyarakat masih cenderung belum mengetahui apa itu "The Light of Aceh" bahkan mendengarnya pun mereka belum pernah. Begitu pun dengan wisatawan yang datang, mereka masih jarang melihat branding tersebut baik di media sosial, 
bus travel dan tempat lainnya.Setelah dijelaskan mengenai logo halal Aceh, juga tidak memberi pengaruh banyak terhadap ketertarikan mereka pada wisata halal di Aceh. Sebagian besar mereka datang berwisata ke Aceh bukan karena mengetahui wisata halalnya, namun karena melihat keindahan alamnya. Media yang paling umum atau sering mereka gunakan untuk memperoleh informasi tentang wisata di Aceh adalah media sosial seperti instagram, dan facebook.

Peralihan politik, ekonomi, dan kemasyarakatan serta perubahan lingkungan hidup di Aceh mempengaruhi pembangunan sektor pariwisatanya. Pemberlakuan hukum syariah telah membawa perubahan dalam pariwisata dari segi produk, pasar, organisasi dan kebijakan. Pariwisata halal telah dipilih sebagai narasi dan visi utama oleh pemerintah daerah sebagai cara untuk menyesuaikan dengan undang-undang dan tuntutan masyarakat yang baru. Perkembangan pariwisata halal telah mendorong pariwisata, terbukti dengan meningkatnya jumlah wisatawan dan perbaikan infrastruktur. Seperti yang dikemukakan tulisan ini, pemerintah memiliki peran penting dalam menyediakan kondisi dan suasana untuk pertumbuhan sektor pariwisata. Walaupun perkembangannya masih banyak tantangan yang harus diselesaikan pemerintah terutama menanggapi kritikan dan keluhan dari para stakeholders.

\section{KESIMPULAN}

Kebijakan Pemerintahan Aceh terkait kepariwisataan masih hanya sebatas pada pengaturan-pengaturan dan belum berorientasi kearah yang lebih strategis dan konfrehensif seperti perumusan master plan kepariwisataan. Regulasi mengenai kepariwisataan yang terumuskan dalam Qanun Aceh No. 8 Tahun 2013 Tentang Kepariwisataan telah menggariskan beberapa hal yang pada intinya adalah penegasan terhadap penyelenggaraan kepariwisataan yang menjunjung nilai-nilai Islam dan kearifan lokal. Pemerintahan Aceh sepertinya ingin mengarahkan sektor kepariwisataannya menuju pariwisata halal. Hal tersebut bukanlah sesuatu yang buruk karena Aceh merupakan salah satu daerah yang tujuan wisata nasional yang diperhitungkan. Karenanya Aceh diikutkan dalam "World's Halal Awards 2016" dengan memenangkan dua katagori yaitu World's Best Airport for Halal Travelers dan World's Best Halal Cultural Destination.

Meskipun begitu, Pemerintahan Aceh tetap dihadapkan sejumlah tantangan yang harus diselesaikan segera, terutama terkait dengan tata kelola kepariwisataan, pengembangan destinasi pariwisata dan pemasaran (branding) sektor kepariwisataan. Mengenai tata kelola kepariwisataan, masih ada kelemahan di kualitas sumber daya manusia (SDM) di bidang kepariwisataan, baik dalam pengelolaan maupun usaha pelayanan pariwisata menjadi salah satu kendala utama pengembangan kepariwisataan Aceh. Pengembangan destinasi pariwisata merupakan hal yang sangat menantang di Aceh karena sifat fisik daerah, efek dari perubahan iklim, fenomena terkait cuaca alami, kesulitan dengan konektivitas dan infrastruktur dasar akan membutuhkan investasi yang sangat besar. Kurangnya promosi dan sosialisasi terkait branding dan citra pariwisata Aceh terutama terhadap stakeholder sektor kepariwisataan. Media promosi yang ditampilkan menggunakan branding "The Light of Aceh" dan "Aceh Halal Tourism". Sebelum mengusung branding tersebut, Aceh telah beberapa kali mengubah branding kepariwisataannya karena kinerjanya kurang memuaskan.

\section{REFERENSI}

BPS Aceh. (2019). Statistik Kunjungan Wisatawan Mancanegara Provinsi Aceh. Retrieved from https://aceh.bps.go.id/publication/2020/01/02/07f7a8f7fd8cl $7 \mathrm{fel} 599 \mathrm{dbc} 8 /$ statistik-kunjungan-wisatawan-mancanegaraprovinsi-aceh--2018.html

Disbudpar Aceh. (2014). Rencana Strategis Dinas Kebudayaan dan Pariwisata Aceh Tahun 2012-2017. Retrieved from http://disbudpar.acehprov.go.id/wpcontent/uploads/2016/08/3.-Renstra-2012_2017.pdf

Disbudpar Aceh. (2016a, July 18). Branding Baru "The Light Of Aceh." Disbudpar.Acehprov.Go.Id. Retrieved from http://disbudpar.acehprov.go.id/branding-baru-the-lightof-aceh/

Disbudpar Aceh. (2016b, September 23). Inilah Isi Rumusan Rakor Kebudayaan Dan Pariwisata Aceh 2016. Disbudpar.Acehprov.Go.Id. Retrieved from http://disbudpar.acehprov.go.id/inilah-isi-rumusan-rakorkebudayaan-dan-pariwisata-aceh-2016/

Disbudpar Aceh. (2018). Rencana Strategis Dinas Kebudayaan dan Pariwisata Aceh Tahun 2017-2022. Retrieved from https://ppid.acehprov.go.id//assets/uploads/3lEl/informasipublik/jbbL/Rencana_Strategis_Disbudpar_Aceh_20172022.pdf

Edgell, Sr., D. (2008). Tourism Policy and Planning. In Tourism Policy and Planning: Yesterday, Today, and Tomorrow. https://doi.org/10.4324/9780080942506

Getz, D. (2008). Event tourism: Definition, evolution, and research. Tourism Management, 29(3), 403-428. https://doi.org/10.1016/j.tourman.2007.07.017

Goeldner, C. R., \& Ritchie, J. R. B. (2012). Tourism: Principles, Practices and Philosophies. In John Wiley \& Sons, Inc., Hoboken, New Jersey. https://doi.org/10.1159/000470892

Hasyim (ed). (2012, January 14). Seribu Tekenan Tolak Best Western. Serambinews.Com. Retrieved from https://aceh.tribunnews.com/2012/01/14/seribu-tekenantolak-best-western

Henderson, J. C. (2003) 'Managing tourism and Islam in peninsular Malaysia', Tourism Manage- ment, 24(4), 44756.

Jaelani, A. (2017). Halal Tourism Industry in Indonesia: Potential and Prospects. SSRN Electronic Journal, (76237). https://doi.org/10.2139/ssrn.2899864

Li, K. X., Jin, M., \& Shi, W. (2018). Tourism as an Important Impetus to Promoting Economic Growth: A Critical Review. Tourism Management Perspectives, 26, 135-142.

Mastercard-CrescentRating.(2018). Global Muslim Travel Index 2018. Retrieved from https:/www.crescentrating.com/download/thankyou.html ?file=X7UrOM8Y_GMITI-Report-2018-webversion $\% 281 \% 29$.pdf

Murdiastuti, A., Rohman, H., dan S. (2014). Kebijakan Pengembangan Pariwisata Berbasis Democratic Governance. Surabaya: Pustaka Radja.

OECD.(2020). OECD Tourism Trends and Policies 2020. https://doi.org/10.1787/fa44fele-it 
Peraturan Pemerintah Nomor 50 Tahun 2011 Tentang Rencana Induk Pembangunan Kepariwisataan Nasional Tahun 2010 $-2025$

Pereira, R. L. G., Correia, A. L., \& Schutz, R. L. A. (2012). Destination Branding: A Critical Overview. Journal of Quality Assurance in Hospitality and Tourism. https://doi.org/10.1080/1528008X.2012.645198

Qanun Aceh Nomor 8 Tahun 2013 Tentang Kepariwisataan

Ridwan, M dan Aini, W. (2019). Perencanaan Pengembangan Daerah Tujuan Pariwisata. Yogyakarta: Deepublish Publisher.

Rindrasih, E. (2019). Life after tsunami: the transformation of a post-tsunami and post-conflict tourist destination; the case of halal tourism, Aceh, Indonesia. International Development Planning Review, 4l(4), 517-540. https://doi.org/10.3828/idpr.2019.15

Rustiana, E., Abdillah, U. W. M., \& Cupiadi, H. (2019). Implementasi Kebijakan Pembangunan Kepariwisataan Di Kabupaten Garut. Conference on Publick Administration and Society.

Saleh, R., \& Anisah, N. (2018). Pariwisata Halal Di Aceh: Gagasan Dan Realitas Di Lapangan. Sahafa Journal of Islamic Communication, $\quad 1(2), \quad$ 79-92. https://doi.org/10.211l1/sjic.vli2.2849

Singh, K. A. U. I., \& Unjum, I. (2016). Tourism in Jammu and Kashmir Economy: Role and Performance. Journal of Economic \& Social Development, 12(2), 112-123.

Swesti, W. (2019). MASYARAKAT DI BANDA ACEH The Social-Cultural Impact of Tourism In Banda Aceh. 13(2), 49-65.

Tim Viva. (2019). "Aceh Halal Tourism", Branding Baru Pariwisata Aceh. Viva.Co.Id. Retrieved from https://www.viva.co.id/gaya-hidup/travel/1191265-lsquoaceh-halal-tourism-rsquo-branding-baru-pariwisata-aceh

Timothy, D. J. and Iverson, T. (2006) 'Tourism and Islam: considerations of culture and duty', in D. J. Timothy and D. H. Olsen (eds) Tourism, religion and spiritual journeys, London, Routledge, 186-205.

Undang-Undang Nomor 10 Tahun 2009 Tentang Kepariwisataan

Wiwin, dkk. (2019). Policy Brief: Strategi Peningkatan Destinasi Wisata Halal Melalui Branding "The Light of Aceh." Banda Aceh.

Yoeti, O. A. (2002). Perencanaan Strategis pemasaran daerah tujuan wisata. Jakarta: Pradnya Paramita. 